INTERDISCIPLINARIA ARCHAEOLOGICA NATURAL SCIENCES IN ARCHAEOLOGY

\title{
Revisiting Aguabuena Pottery-making Through Discontinuity
}

\author{
Daniela Castellanos ${ }^{1 *}$ \\ ${ }^{1}$ Departamento de Estudios Sociales, Universidad Icesi, Calle 18 No. 122-135 Pance, Cali, Colombia
}

\section{ARTICLE INFO}

\section{Article history:}

Received: $8^{\text {th }}$ February 2021

Accepted: $28^{\text {th }}$ September 2021

DOI: http://dx.doi.org/10.24916/iansa.2021.2.13

\section{Key words:}

discontinuity

fractures in space and matter

ethnoarchaeology

ethnography

Aguabuena potters

Colombian Andes

\begin{abstract}
A B S T R ACT
Discontinuity plays an important role in the social and material world of Aguabuena potters, a small rural community in the Colombian Andes. Drawing on long-term ethnographic fieldwork, I explore the changes in modes of production and gender division of work during the last decades of the twentieth century and the fractures in space, memory, and materiality to address discontinuities in ceramic production. The wheel and its transformations are taken as an important factor of these processes. Against the common trend in the archaeology of Colombia to see pottery-making as a static craft, rooted in an indigenous past, this article aims to revisit ethnoarchaeological and ethnographic data to argue how cracks and gaps, besides empirical facts, can be seen as complex analytical lenses through which to embrace ruptures and less linear narratives.
\end{abstract}

\section{Introduction}

This article explores discontinuity as an analytical lens to revisit our studies on pottery-making. Drawing on longterm ethnographic research in Aguabuena, a small closeknit, Spanish-speaking rural community of potters in the Colombian Andes, I address changes observed among Aguabuena potters during the past two decades to reconsider the social and material dynamics inside ceramic workshops at a local scale and the presence of the potters' wheel in these processes. Specifically, I focus on social transformations within the Aguabuena community and territory, technological changes in the ceramic manufacturing process, and surfaces constructed and maintained with ceramic sherds. These aspects, I argue, exemplify forms of discontinuity that challenge the more lineal accounts on pottery-making and invite us to reconsider the role of fractures and fragments, both empirically and theoretically, in understanding a significance of the discontinuities in the world of potters.

\footnotetext{
*Corresponding author. E-mail: dcastellanos@icesi.edu.co
}

The ideas I present draw on ethnographic data taken during various visits to the field that had different duration and combined different techniques (in 2001, 2006, 2009-2010, 2013, 2019). My interest in the relationships between material culture and people guided me through participantobservation of the social life of pots and potters, looking at the various dynamics transcending the manufacturing process of pots. I combined mapping, spatial analysis, indepth interviews and informal conversations, kinship charts, material culture inventories, a pottery-making apprenticeship building a detailed archive made of fieldnotes, maps, pictures, audios, and videos which aided me in witnessing the transformations of Aguabuena from my first arrival in early 2000 and every subsequent visit as well. During this time, the trusty and enduring relations I have managed to build and maintain with some of the families allowed me to explore more collaborative forms of research that helped me to actualise my data through the remote fieldwork.

For instance, discontinuity has been a key concept in archaeology for addressing cultural and social change at different scales of time and space. As Roux and Corty (2013) 
classifications are at the base of periodization intending to correlate horizons of time with forms of social organization of pre-Hispanic groups and by this means trace cultural changes in indigenous societies through archaeological materials. This "tyranny of typology", as some critical scholars call it (see Gnecco and Langebaek, 2006), has undermined other interests including more technological analysis crucial to understanding aspects of the cultural and political ecology of ceramic production and modes, scale, and specialization of craft-making. Moreover, the focus on indigenous groups has overshadowed other interests towards European or African influences on pottery in Colombia (despite the great mix of populations and cultural traditions that historians have documented since early colonial times), including the presence of the potters' wheel or the innovations of firing techniques through kilns after the Spanish conquest or cultural traits coming with the arrival and settlement of black slaves, themes only explored more recently within the field of Historic Archaeology (e.g. Therrien et al., 2002; Ome, 2006; Mantilla Oliveros, 2016; Patiño and Hernández, 2020).

The interest in the pre-Hispanic past has also driven a few ethnographic and ethnoarchaeological studies in ceramics. Since the pioneering study of Ann Osborn on the pottery of Tunebos (today the U'wa, an indigenous community of the north-eastern Colombian Andes) in the late seventies, the ethnographic present has interested scholars for the remaining indigenous features that may link the past and the present. In other words, an interest in continuity (and by this token transformation) has led the approach to today's craft-making processes, while trying to establish a kind of indigenous atemporal essence bridging archaeology, ethnography, and ethnology.

In this context, the presence of the potters' wheel, in both the archaeological and ethnographic records, has been understudied, as it is not considered a key element in the understanding of the indigenous world. This research agenda has been questioned more recently by other scholars who, on the one hand, problematise the conceptualisation of a preHispanic indigenous past, free from colonial distortion (see Langebaek, 2012; 2019; Rappaport, 2018), and on the other hand, have documented the rich and complex social and cultural dynamics of the colonial period, intervening and re-signifying the indigenous lives and repositioning them in the colonial period (see Therrien et al., 2002; Ome, 2006; Loboguerrero, 2001). In this same vein, the critical approach of authors like Langebaek has been crucial in revisiting and challenging ethnohistory and archaeology in light of their fabrication of discourses and analytical models under the guise of colonialism and despite their status as scientific disciplines. ${ }^{4}$

\footnotetext{
4 In one of his latest books "Los Muisca", Langebaek (2019) shows how the category of cacique and chiefdoms as a form of social organisation are constructed and employed according to the interests of the colonial Spanish officers of the sixteenth century onwards. Archaeology and ethnohistory still perpetuate the colonial legacy which they intend to question by assuming these categories as less critical which undermine the variability and cultural diversity of societies encountered by the Spaniards upon their arrival to the New World.
}

The haunting of the indigenous past in academic research has made continuity a guiding aim in studying potterymaking. This is expressed through ideas of the long duration of techniques and technologies across spatial, temporal, and social scales and which do not engage with the fluid setup that, for example, colonisation brought in the Americas. The categorisation of coiling as a "traditional indigenous technique" vis-à-vis throwing as a typically European one, established fixed boundaries for what were considered local and traditional products versus what is classified as foreign, modern, and therefore non-indigenous. Furthermore, this distinction is difficult to maintain empirically, as a vessel that gets started on a potter's wheel can then be finished with the coiling technique (see Arnold, 1985) and, more recently, in typological studies revisions have been made in addressing the complexity and richness of the archaeological materials (see Therrien et al., 2002).

The representation of pottery-making as a cultural heritage of the Colombian nation has been another aspect contributing to its fixed and stable image. For example, Ráquira, the region where Aguabuena is located (Figure 1), is identified as a "pueblo de olleros" (a town of pottery makers), a term first coined in official documents of the early eighteenth century by Spanish officers describing the lives of the indigenous people, and then made popular through the joint collaboration of academic and applied research in the area, to the extent of becoming a term widely spread (see Duncan, 1998; Orbell, 1995; Mora de Jaramillo, 1974; Ministry of Culture, 2014).

The two main archaeological surveys done in Ráquira in the 1970s and 1990s (see Falchetti, 1975; Broadbent, 1974; and Therrien, 1991) documented the small scale of ceramic production in contrast to the large scale reported in documents of colonial times problematising the "pueblo de olleros" name. These studies used ethnography as a tool for gathering comparative data on ceramic materials tracing today's continuation in techniques and ceramic technologies from the past.

Here it is worth mentioning the work of Monika Therrien at length, for providing a middle ground in the tension around the category "traditional" in Colombian archaeology. For this scholar, transformation and continuity are mutually embedded in the archaeological materials (Therrien et al., 2002) and they should not be generalised or extrapolated from one context to another, but instead they need to be assessed at different scales, ranging from regional patterns to singular archaeological sites (Therrien, 2016). In this sense, her early work in the 1990s, excavating an archaeological record from a discard area of a colonial ceramic workshop in Ráquira, is pioneering in its attempt to establish the coexistence of traditions that were thought to be unrelated. For this purpose, she uses ethnographic data from the region and other places in Colombia to enrich her archaeological interpretations. She was able to compare the pottery techniques from indigenous groups like the Tunebo (Osborn, 1979) and Emberá-Chamí (Vasco, 1987) with the ones she documented among living rural potters in Ráquira or previous scholars registered in the same area (Broadbent, 


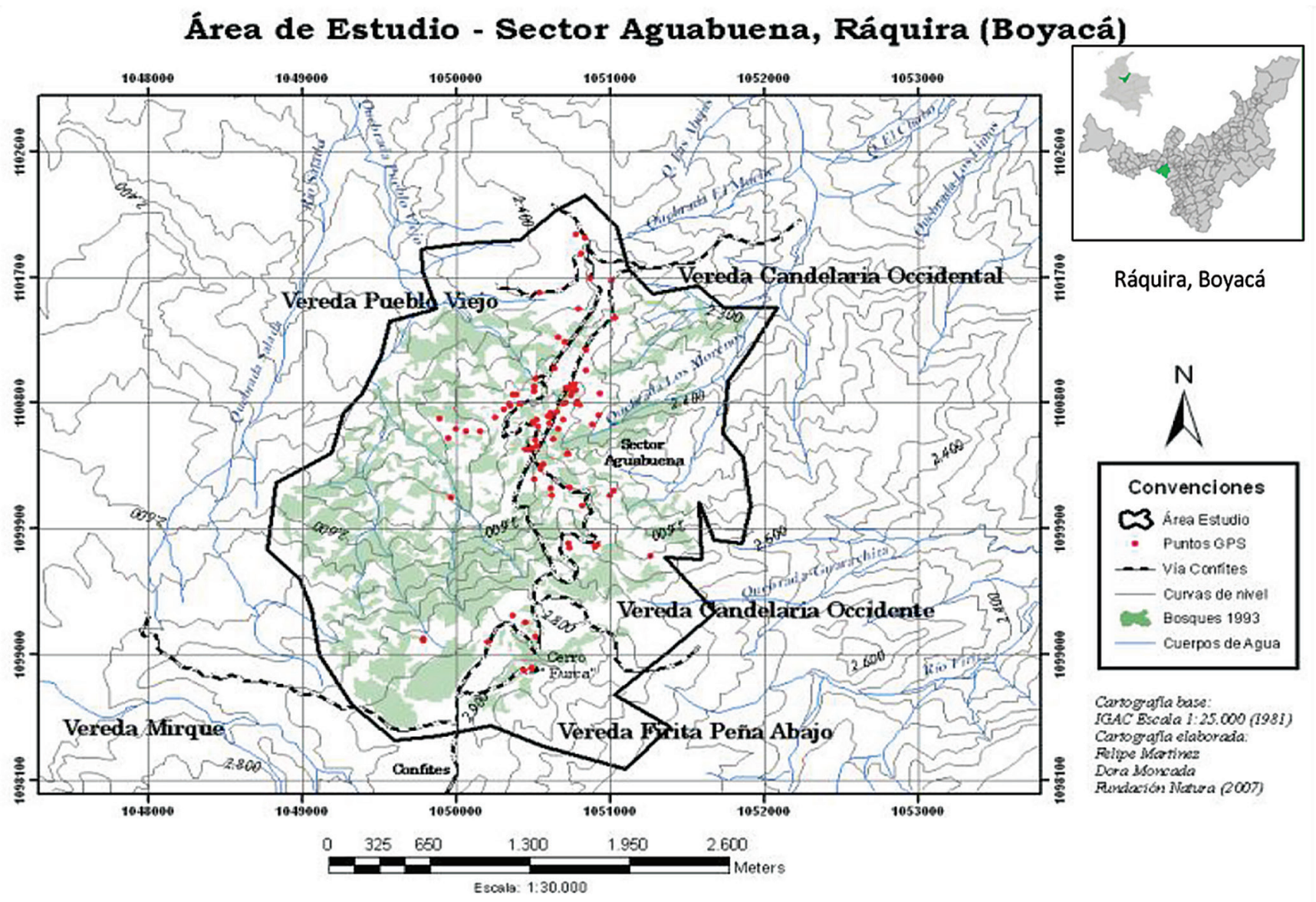

Figure 1. Location of Aguabuena within Ráquira. Red dots correspond to active ceramic workshops in 2007. Source: Rasmussen (2010, p.277).

1974; Mora de Jaramillo, 1974) and neighbouring towns like Sutamarchán and Tinjacá (Falchetti, 1975) (Figure 2). Therrien refers to the use of "plato", a rudimentary form of wheel consisting of a ceramic small plate placed on a wooden table on the ground towards which the potter kneels to shape the vessel while she manually spins the plate in a slow manner. This same feature was ethnographically documented two decades before by Falchetti (1975, p.212), who stated the possible nexus between the plato and what she called the "proper wheel", the former characterised by slow and interrupted movements, while the latter was by a rapid and continuous movement.

Data collected in Ráquira and surroundings empirically proved the coexistence of different pottery manufacturing techniques in archaeological and ethnographic materials (like coiling and modelling) and the use of rudimentary wheels as part of the ceramic technology employed in colonial ceramic contexts with reference to other ethnographic contexts in different regions and among different indigenous groups in Colombia (Therrien, 1990, pp.40-41). Despite this evidence, archaeologists still pursue "pure" categories of fixed boundaries between what is indigenous and what is not, with little interest towards hybridisations and forms of mestizaje also visible through ceramic technology.

Artesanías de Colombia (AC), a half-state, half-private institution in charge of craft promotion, marketing, and export in Colombia, represents another important actor intervening on the ways state agencies and multilateral and non-governmental organisations see and assess potterymaking, as well as influence academic research, through its technology and capacity building programs. With clear interventions in Ráquira since the sixties in both design and technological transfer (e.g. implementation of sustainable and clean technologies), AC has contributed to tensions between the need for a renewal of traditions and a search for innovation - and the sectors identifying with those endeavours (the rural potters of Aguabuena being representative of the more "traditional" side). ${ }^{5}$

\footnotetext{
Let me illustrate this point with few examples. The AC initiative of replacement of the usual coal kilns for electric or gas kilns with the financial and technical support from international cooperation, although was enthusiastically promoted by local majors, was widely rejected from the side of Aguabuena potters. Few kilns were constructed, but potters used them rarely and with time they preferred to quit them, arguing that it was more expensive and riskier to fire pots in them than using their coal kilns. Vessels came out raw or very "pale" (this is without the characteristically burnt orange colour that identifies the craft from this region), potters claimed. In these frictions also stand more traditionally oriented local discourses placing the craft close to indigenous roots and as cultural knowledge transmitted through kinship ties. Defending "la tradición" (the tradition), some potters resist changes in their modes of production proclaiming themselves as guardians of an endangered heritage.
} 
Figure 2. Locations of places and indigenous groups mentioned in the text.

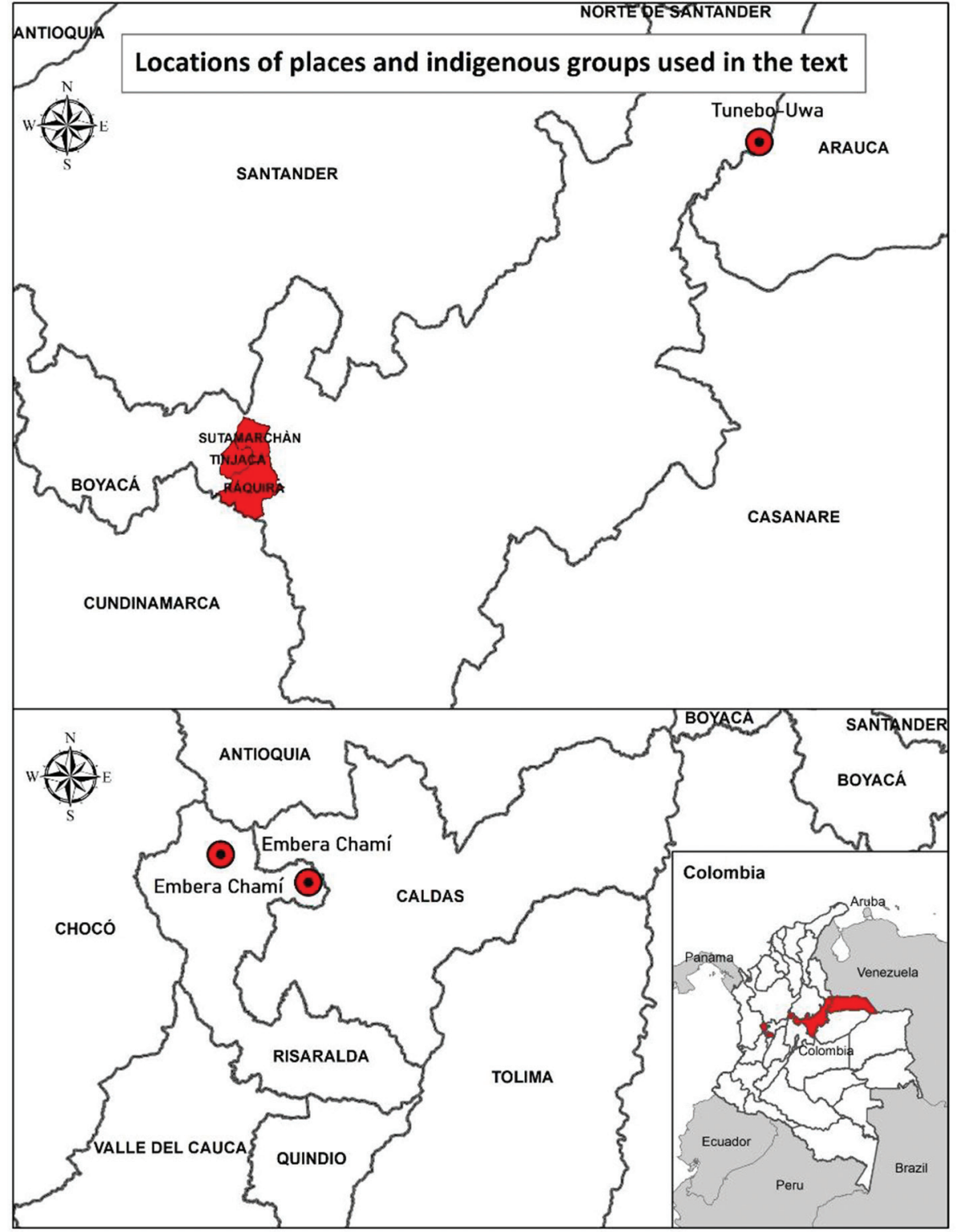

\section{Aguabuena: fractures in/through space and memory}

Geographically, Aguabuena is one of the hills surrounding the town of Ráquira in Andean Colombia. The name refers also to the potters who live there, and who are related by kinship and compadrazgo ties, and share land-tenure practices. Despite having such a strong correlation with a precise feature of the landscape, the place does not appear in the political-administrative maps of Ráquira (which includes all the districts that make up more than $233 \mathrm{~km}^{2}$ of this territory). This invisibility in state records stands in sharp contrast with the high visibility of the hill and renown of its people and their ceramic products (which are popular in the local and national handicraft market).

The name Aguabuena was first coined as the name of a finca (farm) owned by the grandfathers of a generation now in their late seventies. This finca was divided among six siblings and their children. Over the years, this large extension of land became fragmented across three generations in a scheme of land tenure among peasants known as minifundismo (partible inheritance), a characteristic of the whole Boyaca region and a process rooted in the colonial period (see Borda, 1979). This system, however, overlapped throughout the twentieth century with the practice of cousin marriage as well as spatial residence patterns, creating a ramified and interwoven universe of kin relations and land rights. In sum, the original property has been divided ever since among siblings and their children. Today, "Aguabuena" clusters the descendants of those inhabiting the area and whose kinship ties, and also craft technology, have spread throughout the territory (Castellanos, 2015).

Around the 1980s, those born in the Aguabuena finca became the people known and recognised as Aguabuena potters, or the "people of the hill", thanks to the creation of 


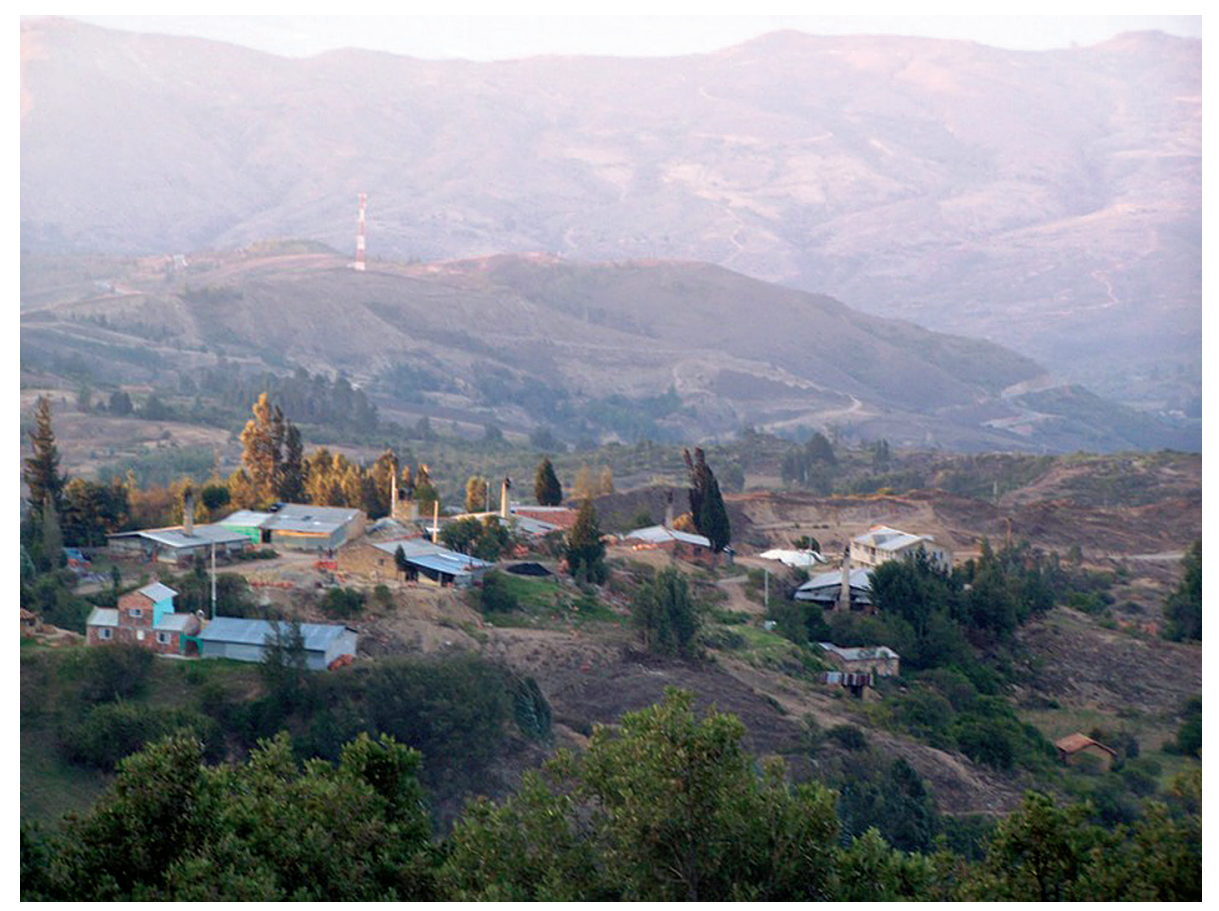

Figure 3. View of a fragment of Aguabuena. Picture taken in 2009 .

an association which gained political recognition from the local authorities. However, their acknowledgement did not translate into a territorial reorganisation of Ráquira with new limits for its rural districts. Aguabuena became a separate social and spatial unit (with its own elementary school and micro football pitch: two key types of infrastructures of rural Colombia), but was not politically independent and remained, instead, part of two rural districts (Pueblo Viejo and Candelaria Occidente) (Figure 1).

The fragmentation of this territory has witnessed the (re) population or emptying of the area, a phenomenon I have followed since my first arrival in the early 2000s. And parallel to the peoples' movement, Aguabuena has been expanding or contracting. For example, between 2009 and 2010, there were 150 potters, divided among 30 workshops scattered on both sides of a dusty road crossing the hill (Figure 3). In December 2019, during a short visit, I registered a highly decreased population of 20 potters and no more than 4 workshops still active. This contraction, however, has changed slightly with the pandemic of 2020, as some families returned to their workshops, escaping the large cities as a way to keep safe from the coronavirus and economic crisis.

This instability gets inscribed spatially as Aguabuena's borders change too. During my first fieldwork, since no official map was available, I charted a map of the area with the help of several of my informants at that time. The territory's boundaries showed the great instability of the place as its limits were a contested issue among the same potters. No matter how contradictory their answers were to me, however, people's depictions were always grounded to their relatives' locations.

For example, in 2001, Doris, a young potter woman said about Aguabuena: "Aguabuena is... you climb the hill and there is a small path from there towards there (she points with her finger drawing an imaginary line from one point of the mountain to another one) ...but that is not Aguabuena, instead it is Candelaria Occidente, but nevertheless is also Aguabuena. Aguabuena is Teresa, the school, from there up to Blanca and Samuel, then my brother, and from there you follow a small path until you reach Yesid and Clotilde."

In 2009, Dori's depiction of Aguabuena changed slightly as one of the families moved downhill, establishing themselves a bit further from the rest of the workshops.

The rapid adaptation that Aguabuena potters have experienced relates also to the dynamism in which they assume these changes, thanks to a great detachment from their past. This lack of interest and of engagement towards their ancestors and their craft contrasts with other craft communities in Colombia, especially those with strong ethnic identity and active in the politics of memory, keen in perpetuating the craft as a cultural and ethnic heritage (see, for example, Vasco, 1989; Chaves et al., 2014). It also goes against the narratives, discussed earlier, that state and private actors along with academics have created of pottery-making. Far from making them proud, or increasing their status in the local setup, for younger generations in Aguabuena, being a potter represents a certain backwardness and a stigma for being dirty and covered with clay on their bodies and clothes. Taken as a hard, poorly-paid, and exploited type of work, youngsters have also been encouraged by their parents to become "moderns" and therefore migrate to towns employing themselves in different economic activities. ${ }^{6}$

\footnotetext{
Although majority of young people have decided to quit pottery-making, there is still a minority who see it as a legacy that they need to preserve. This discourse is partly promoted by the arrival of urban people to Aguabuena involved in a re-indigeneity process which has brought a revival of indigenous ontologies and ways of living, including forms of agriculture
} 
Figure 4. Kiln of los antiguos. Picture taken in 2010 .

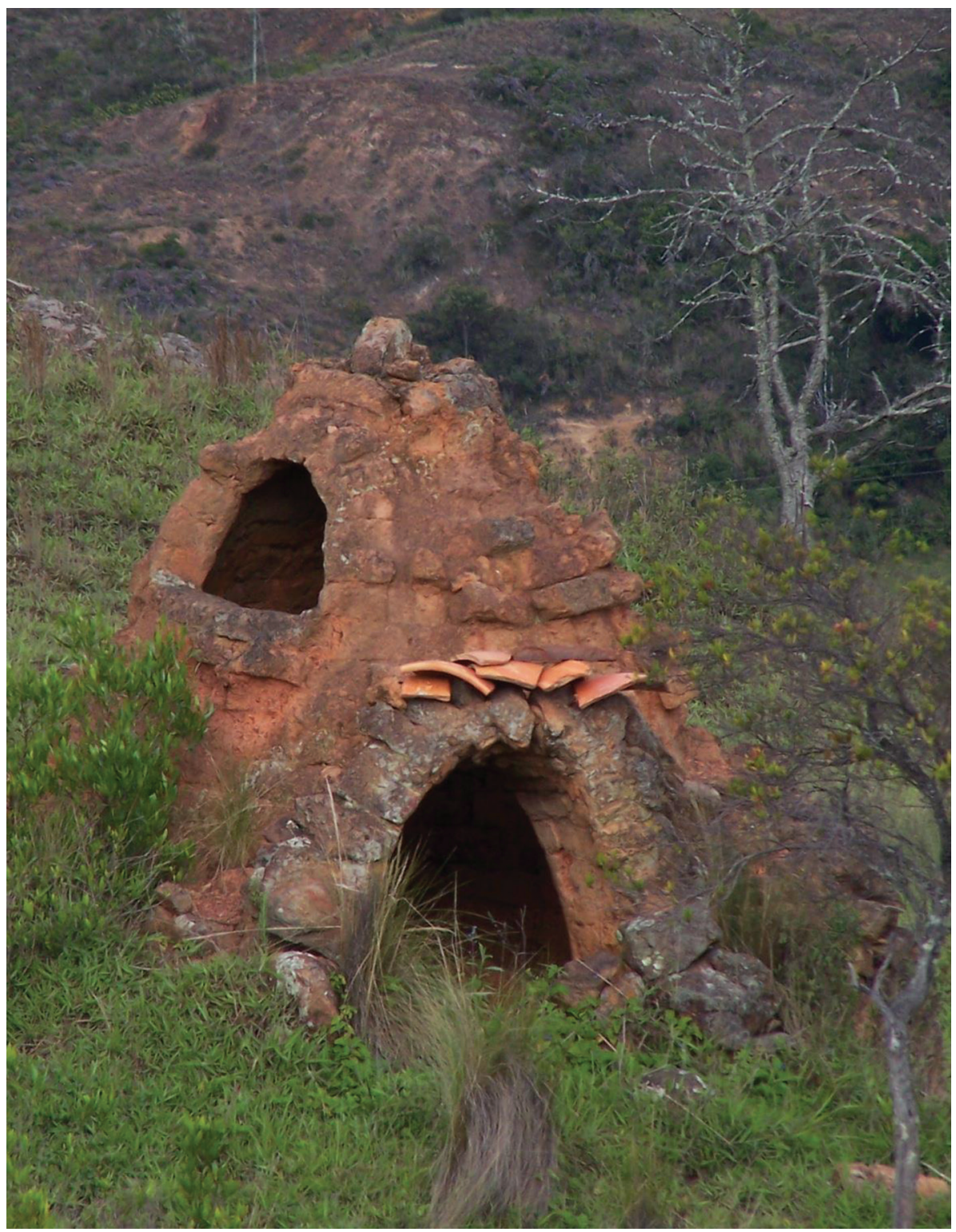

Contrary to the assumption of a direct link between today's craft and pre-Hispanic groups, potters do not explicitly relate their ancestors or their craft to any indigenous populations prior in the area upon the Spanish officers' arrival. Instead, potters declare themselves descendent of los antiguos (the ancient ones), kindred whose presence is traceable through ruins of kilns or abandoned workshops as well as ceramic sherds scattered across the hills (Figure 4). Los antiguos, although from a different time, are still contemporaneous to them, as their traces are visible on Aguabuena's surfaces. Although not caring much about them or who they were, in some cases potters trace back los antiguos in their kinship descendent lines, although more often they ignore who they were. This ambiguous relationship is not the same when they assess the material remains which they clearly recognised

and crafts. Some of the abandoned ceramic workshops have been occupied by these newcomer families who have tried to integrate into the Aguabuena community. were from another time, highlighting the difference in the paste and the ceramic technology.

One day Teresa, one of my key informants, discussed the differences between ceramic sherds from los antiguos and those of current potters, she said: "Ceramics from los antiguos are thinner and have a different colour; some have decorations, whereas ours are thicker, mainly orange, with no sand [used as temper]." The differences pointed to different techniques (of manufacturing and firing), which in turn imply different uses. As the potters explained, "la loza antigua (antique potware) served for cooking while the current one is mainly for decoration".

Other potters, though few, connect their craft to the Spanish world, stating that the Augustinian monks who founded the Candelaria Monastery (located at the bottom of Aguabuena hill) at the end of the sixteenth century were the first ones to do pottery-making in the area. The claim is interesting as it opens up the possibility to think of pottery craft as a product of colonial encounters (e.g. between Europeans 


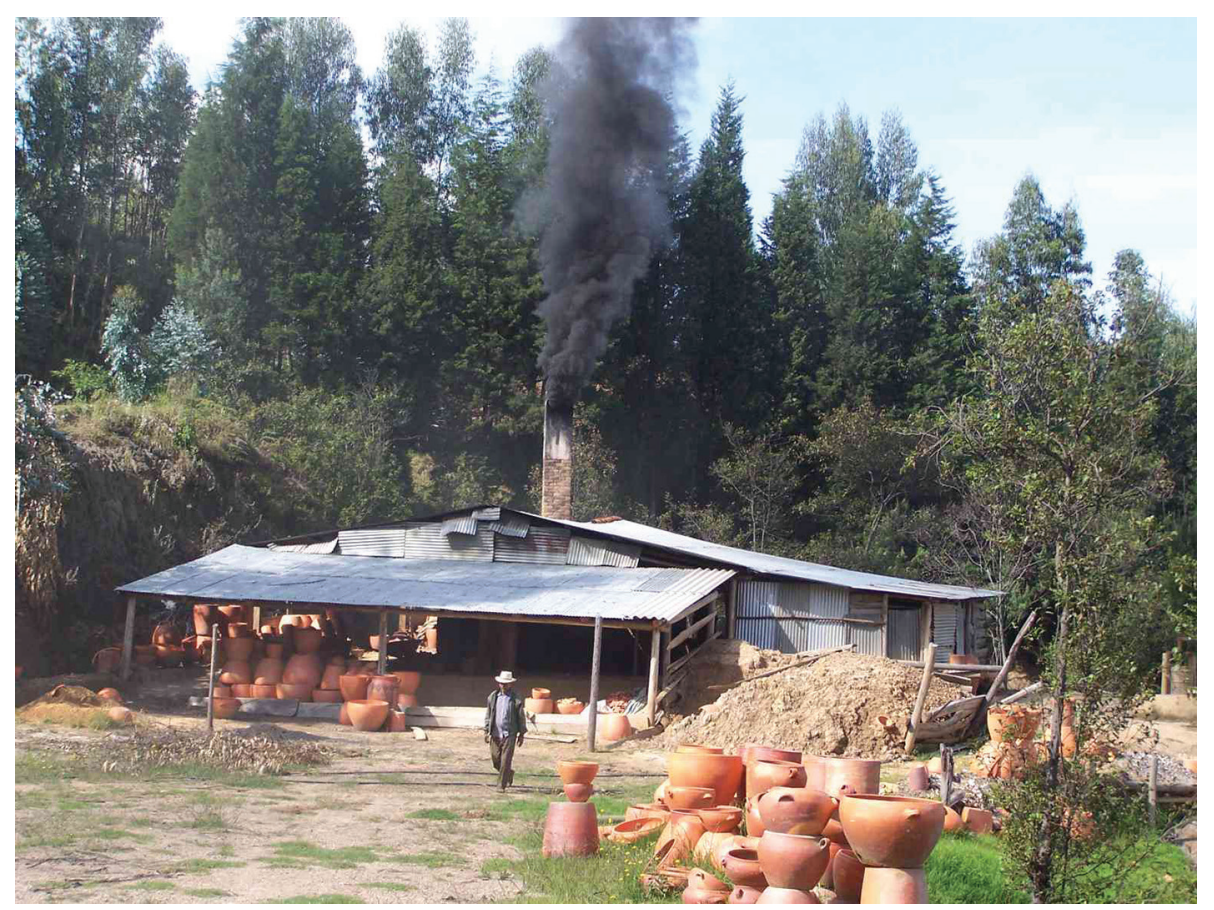

Figure 5. View of the enramada of an Aguabuena fábrica. The picture captures the moment when the kiln man finished the firing and is going to the house to rest after 36 hours of hard labour. Picture taken in 2006.

and indigenous populations), an idea which goes against more essentialist portrayals of current pottery-making as the survival of indigenous traditions.

\section{Discontinuity inside ceramic workshops}

My ethnoarchaeological research focused on the spatial organisation and material culture of a small sample of ceramic domestic workshops ( 8 in total) located in Aguabuena. The aim of the project was to document, a la
Schiffer (1995), the cultural formation processes of ceramic domestic production units as a step toward contributing to alternative methodologies for interpreting the archaeological records of ceramic workshops. For this purpose, I followed the life cycle of vessels and mapped the activity areas of the workshops with special attention to the discarded areas. I combined this with participant-observation of the social dynamics of households and their kinship networks, and the life stories of potters and their ceramic objects. The project aimed to problematise the low rate of ceramic material in the previous archaeological surveys reported in the 1970s

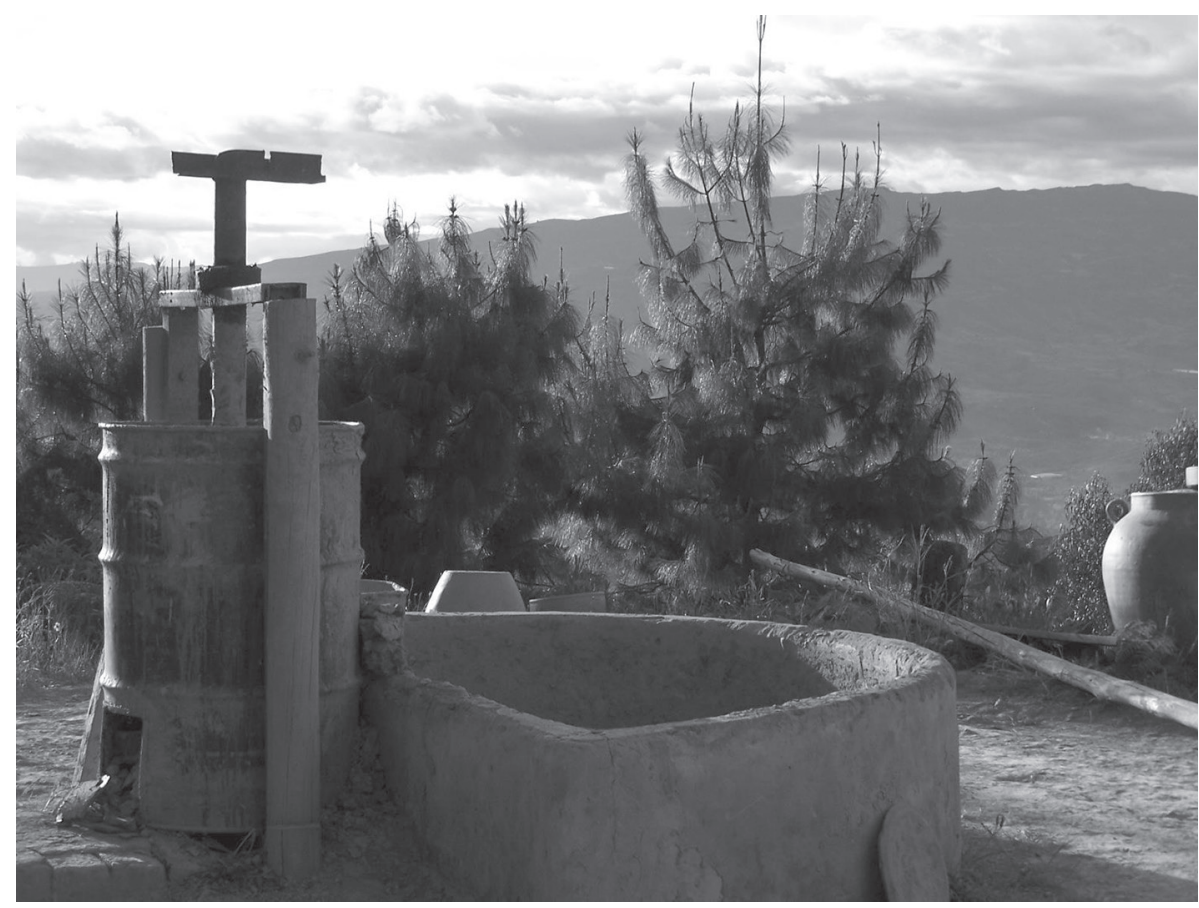

Figure 6. Closer look at the tank and timber cylinder where "moler" is performed. Picture taken in 2006. 
Figure 7. Potter woman performing the conar technique. Notice the ceramic plato on the wooden board and two "conas" (vessel shapes) at the back ready to be shaped. Picture taken in 2009

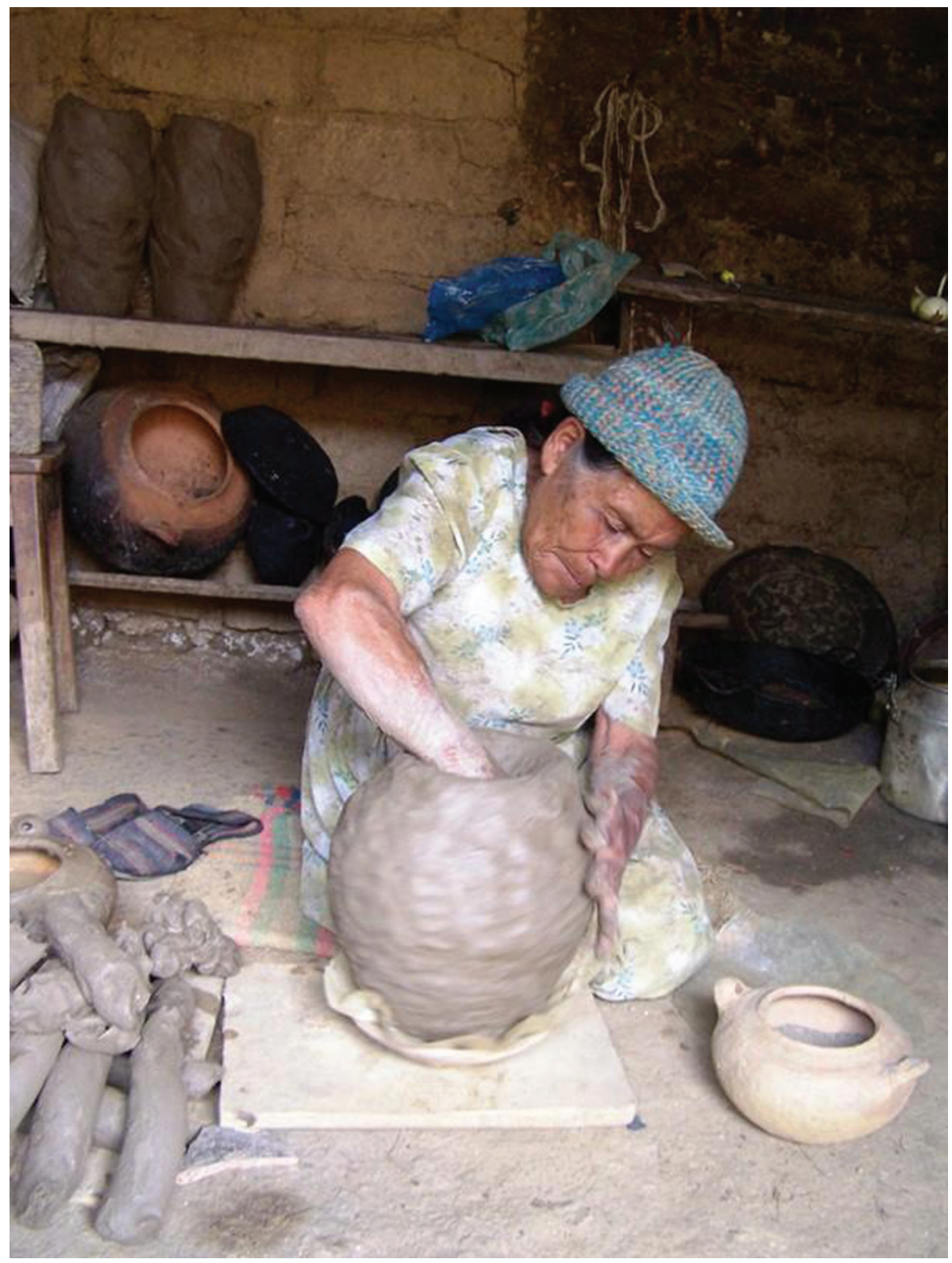

and 1990s and the archaeological low visibility of ceramic workshops, as opposed to the high frequency and visibility seen in the present, and the craft specialisation suggested by the colonial officers who visited the area, particularly in the eighteenth century (Castellanos, 2004).

At the time I did my research, ceramic workshops were transforming their mode of production: they were turning into what potters called "fábricas familiares", i.e. from domestic production units into family factories (Figure 5). Let me explain in more detail the changes which occurred in the production process as a result; although it should be noted other changes in the distribution and consumption accompanied these transformations. In the first mode, women were in charge of the manufacturing techniques and men were only involved in the firing, and pottery-making was performed seasonally (coinciding with the dry months), and the pots produced were utilitarian. The latter one, involved the whole family in the manufacturing and firing, and it was a full-time activity through which ornamental vessels were produced. These changes meant, in turn, a higher investment in technology with a rearrangement of the productive space inside the workshop. For example, the one chamber fuel kiln was changed for a coal kiln of bigger capacity for which potters constructed a semi-closed and under roof space, an attachment to the house, called "enramada". Other investments included the construction of a cement tank in the open space where clay lumps were put together with water and left for a couple of days before putting them inside a timber cylinder connected to a wooden mill, then put into motion with a mule herd led by potters (Figure 6). This process, known as "moler" (to mill), allowed potters to process the clay-bought from providers who brought it from mines located in the region-much quicker and in larger amounts than in the previous way in which potters 
would put the clay lumps (obtained in their own clay mines) in pots, mix them with water and after some days display the moist clay on the patio where they would mix the material with sand (used as temper) with their feet, a physicallydemanding task called "pisado" (stepping).

This move towards craft specialisation in Aguabuena was accompanied by readjustments in the potters' wheel. The ceramic plato, documented by earlier works and still used by domestic workshops, was replaced by a steel mechanical wheel known as a "torneta". The change triggered transformations in manufacturing techniques and the gender division of work. The plato, a feminine object (sometimes inherited from mothers to daughters), put on a wooden board on the floor, was coupled with the kneeling body of a potter woman who would be modelling a pot, a technique called "conar". This technique is said to be highly demanding, requiring skill and body endurance and an old women's expertise no longer practised by young female potters (Figure 7). In turn, the torneta, required a sitting body (male or female) that would coil, in potters" words "armar" (a pot) until reaching the desired height (Figure 8). There, on the torneta, vessels were finished by scraping their surfaces with a sharp tool to smoothen the outside surfaces.

Potters recall the replacement of platos with tornetas at the end of the 1970s to the beginning of the 1980s and as a concomitant process with the construction of coal kilns. The torneta was introduced by one of the main middlemen of Ráquira, who also owns an industrial workshop in the town. His constant travels to distribute pots to big cities and his connections to Artesanías de Colombia (making him a regular beneficiary of innovation and building-capacity workshops) exposed him to different technologies for manufacturing and firing ceramics. Thus, technological innovations transformed pottery-making in Aguabuena, although with an increased

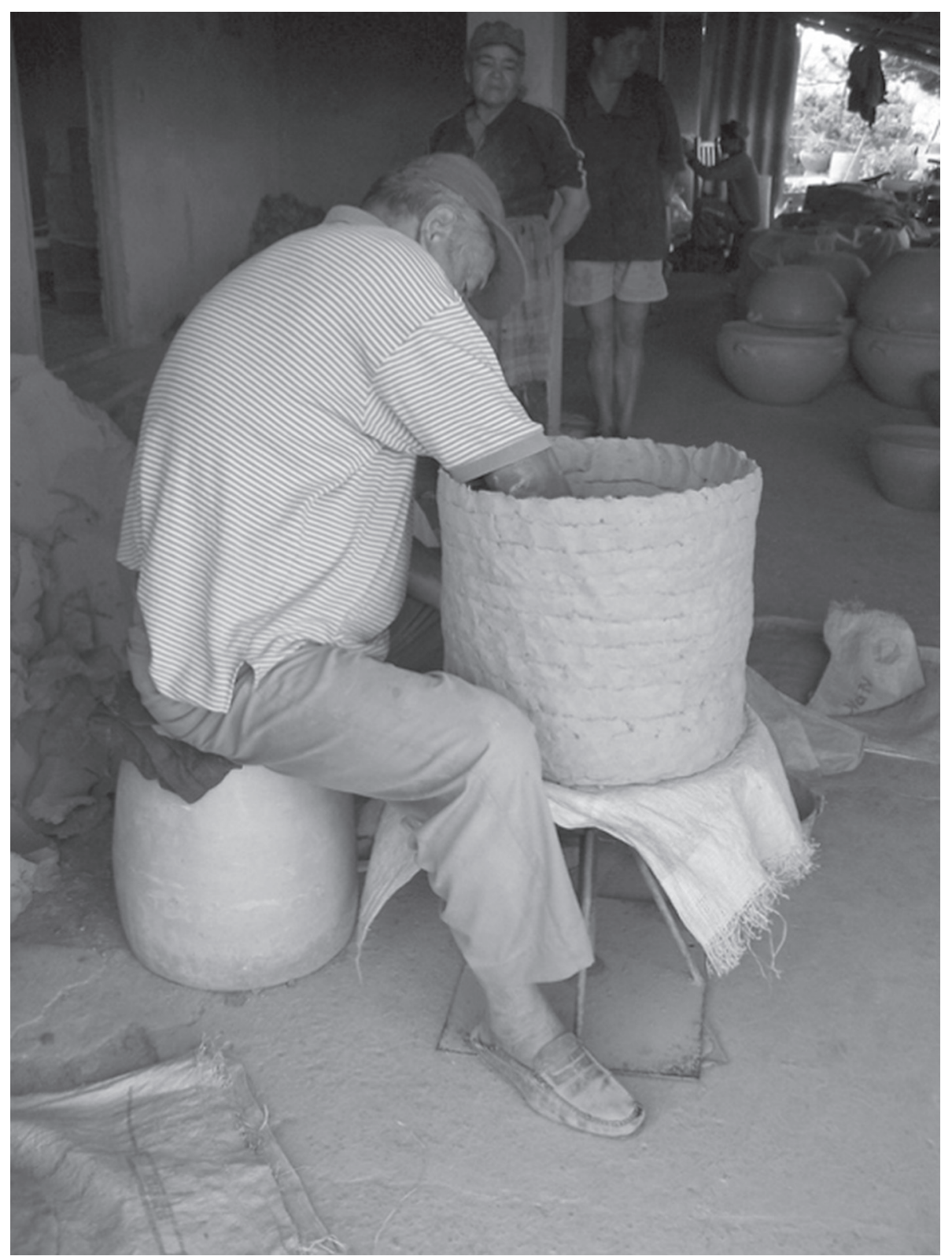

Figure 8. Potter man sitting in front of a torneta smoothens the inside part of the vessels after finishing coiling. Picture taken in 2006. 
Figure 9. Potter woman scrapes a vessel while watching TV with her oldest son. Picture taken in 2009.

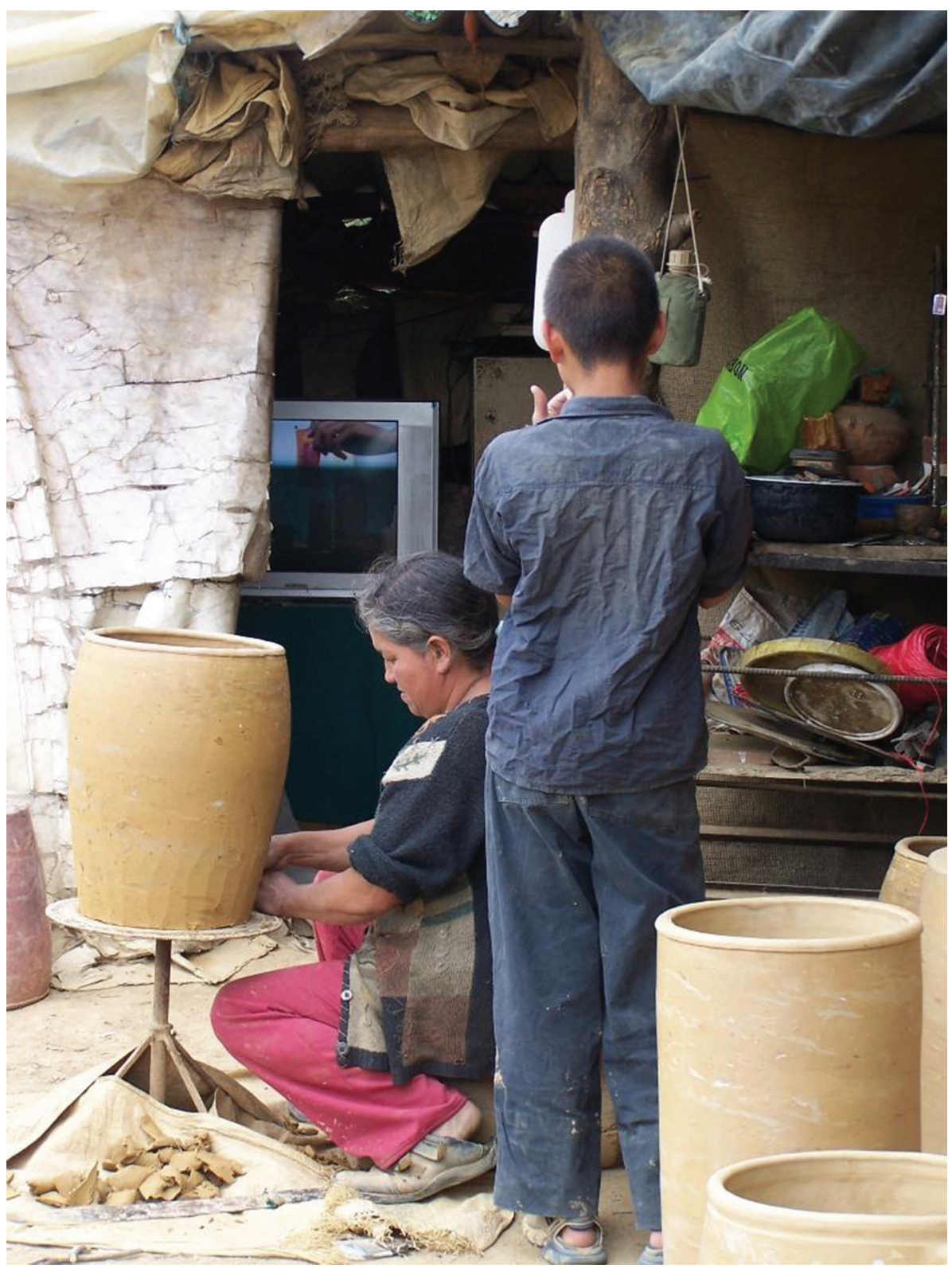

dependency on middlemen (for acquiring raw materials and for distribution and commercialisation of their craft) placing potters in relationships of greater exploitation.

Despite production being considered easier to localise and study, from an archaeological point of view, in contrast to other economic activities like distribution and consumption (see Costin, 1991), a closer look inside a ceramic workshop's microcosm reveals that some key activities are still difficult to be traced in the archaeological record. The distinction between flexible and restricted spatial activities proposed by the ethnoarchaeological study of Arnold III (1991, pp.100-101) points out these difficulties, making us reconsider the different archaeological visibility that ceramic tasks may have in the production units.

For example, my data in Aguabuena showed that only a very small proportion of ceramic waste is discarded and that mostly broken pots or ceramic sherds are reused for several purposes. $^{7}$ Moreover, most of the steps of manufacturing which excluded firing were spatially flexible with low archaeological visibility (Castellanos, 2004). Even a metallic and heavy tool like the torneta had no specific place in the workshop and could be placed in several spots depending on the spatial organisation of the working space and in response to the different needs of a household. Located at times next to clay stored ready to be used, the torneta could also be found far from materials or other technological facilities (Figures 9 and 10).

Indeed, spatially-flexible activities posed a methodological challenge for my ethnoarchaeological study as it seemed that there were no clear patterns for the activity areas of a ceramic

\footnotetext{
In a sample of 237 objects registered in 8 domestic workshops, $12.7 \%$ corresponded to discarded ceramic vessels and $58 \%$ to pots in a reusable state (Castellanos, 2004, p.36).
} 
argued, more than a concept itself, discontinuity defines a quality of change within the framework of evolutionary theory addressing a cessation of transmission of a cultural trait, for example, when there is a change in population (2013, p.189). ${ }^{1}$ Under this view, discontinuity is the benchmark to a processual shift or turn in society, never directly observed but rather inferred though different theoretical frameworks of models of behaviour.

As for ethnoarchaeology, discontinuity yields the type of analogy researchers can methodologically employ for their ethnographic data to address their archaeological questions. If there is a striking historical discontinuity between the present and the past, such as differences in population, cultural traditions or environmental conditions, analogies are considered less strong and therefore significantly less robust. Gould and Watson called these analogies a "general comparative approach" that is discontinuous in nature as opposed to the "direct historical approach" emphasising continuities through time (see Gould and Watson, 1982, pp.371-372). ${ }^{2}$

My approach to discontinuity is ethnographically oriented and inspired in the more general material-culture studies field within Social Anthropology. Drawing from the "thinking through things" call (see Henare et al., 2007), I seek to engage with artefacts and materiality in their own terms, following how material fractures, gaps, and broken pieces embed and animate social life within a context of ceramic manufacture. This means, in the words of Henare et al. (2007, p.2), "to take 'things' encountered in the field as they present themselves, rather than immediately assuming that they signify, represent, or stand for something else". From this point of view, concepts and things are not different (Henare et al., 2007, p.1; see Gordillo, 2014) and matter, therefore, conceptually speaks from its own physicality. Keeping this in mind, discontinuity is a quality not of change (like in the evolutionary theory) or analogy, but of materiality observable in different surfaces: in the soil, in the land and in the ceramic vessels or sherds. In other words, the question being addressed in this article asks: What does discontinuity, examined through broken surfaces and ceramic fragments, tell us about potters and potterymaking? And what would our studies on pottery-making gain if in more analytical terms we embrace the discontinuities that we empirically observe?

Of course, one could argue that archaeologists have answered this question in various ways and through different

\footnotetext{
1 These authors propose to contextually locate the absence and presence of cultural traits through units of transmission identified as social, institutional structures or populations (Roux and Corty, 2013, p.189). In their effort, Roux and Corty $(2013$, p.189) bring to the fore Braudel's three types of historical time (long, medium, and short) corresponding, in turn, to changes of different orders (social, circumstantial and event based), which is an analytical framework very useful for archaeology.

2 Sillar and Joffré (2016) explore the uncritical use of "direct historical analogies" in the Andes based on frequently stated or assumed historical continuity. In their paper, the authors question the relevance of analogy and call for a more detailed contextualisation of the ethnographic data leading to a better assessment of the changing social context of the apparent continuities.
}

methods, showing us indistinctively how fragments can speak and inform us about the society and social system in which they were produced. However, what other stories and theoretical ideas may emerge if we consider fractures and fragments themselves? What if we take cracks and gaps as analytical lenses? And what can we say about those whose experiences engage with fragmentations?

These questions are interesting to consider in light of the potter's wheel, an artifact associated with cultural change and innovation within ceramic studies, somehow a mark of discontinuity (see Knappett and van der Leeuw, 2014; Roux, 2003). Despite its association with the specialisation and intensification of craft making, the wheel has been understudied in the archaeology of Colombia. This lack of interest is partly related to the prevalence of stylistic analysis in ceramic studies over more technological ones, as well as the focus on the identification of Prehispanic indigenous traits in the archaeological materials, an identification which excludes the wheel for associating it with non-indigenous features.

Drawing from these presented ideas, the discontinuity I refer to is spatially located rather than temporal, and although significantly situated in a horizon of time of the ethnographic present, still informs us on different (nonlineal) temporalities. ${ }^{3}$ My focus on discontinuity is threefold: first, the Aguabuena limits and the spatial distribution of workshops across this territory; second, the distinction between spatially flexible and fixed manufacturing activities within the ceramic workshop; and third, the materiality of paths made of ceramic sherds. In what follows, I expand on these forms of discontinuity pointing at how they can challenge and enrich our ways of studying pottery-making. While doing so, I reflect on how my ethnographic attention to fragments has led me to think through cracks and gaps analytically (Castellanos, 2020).

Before addressing these points, let me first turn to the ways in which pottery-making has been explored in the Archaeology of Colombia and the scarce interest shown for the potter's wheel in these studies. As I shall show, this limited attention relates to a strong engagement from archaeology's side to reconstruct a lineal history in which indigenous past and present are linked without disruptions and discontinuities.

\section{Pottery-making and the wheel in the archaeology of Colombia}

Pottery-making is mainly explored from the stylistic point of view in Colombian archaeology. With a prime interest in defining ceramic typologies within cultural areas, stylistic

\footnotetext{
In their book "Ethnoarchaeology in action" David and Kramer (2001, p.50) consider the limits set by the "tyranny of the ethnographic present" for those studies whose ethnographic materials aim at answering archaeological questions. Archaeology deals with change over the long term (diachronic), whereas ethnography documents short-term variability (synchronic). The differences in temporality can be also described as the former engaging with processes and the later with mechanisms.
} 


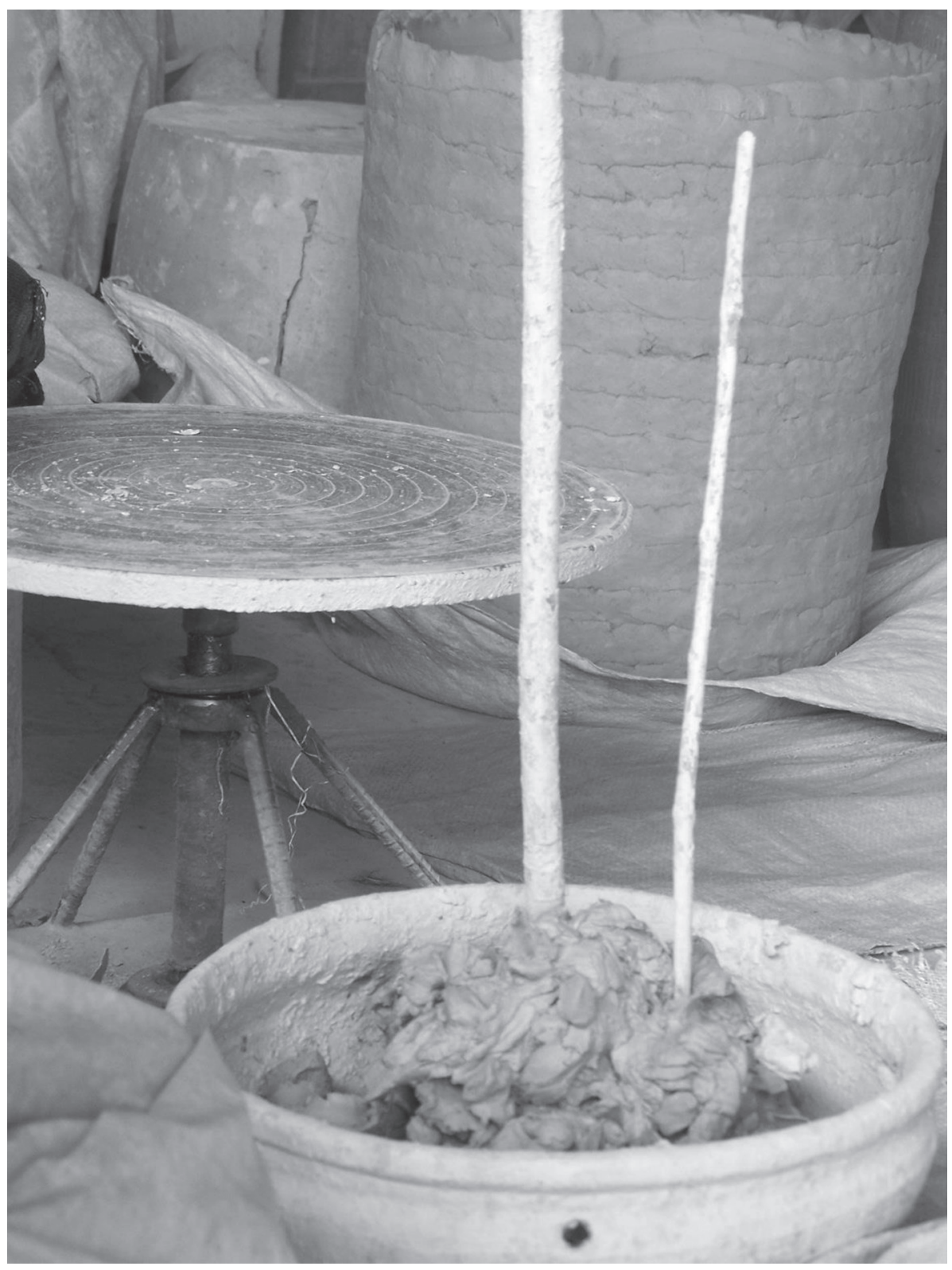

Figure 10. An empty torneta next to a vessel containing leftovers of dry clay. Notice the two sticks used as scales to indicate the height of some types of vessels. Picture taken in 2006

workshop in terms of use of space or distribution of material elements, many of them being "portable objects" (see Costin, 1991, p. 19). The patio, for example, the open space of the workshop and one of the most intense spaces in terms of its use, however, got emptied every time a new activity would start, erasing the possible records of these activities on the surface. Space was emptied and reoccupied with various sets of tasks, mixing the manufacturing and quotidian activities of a household: drying a wet cloth, cooking or grilling on an improvised hearth on the ground, drying and selecting corn and beans for cooking or storing, family celebrations, amongst other things.

Thus, constant circulation of people and things made workshops a dynamic matrix where discontinuity arose through the spatial disruptions of social rhythms, bringing in turn a material juxtaposition and mixture that could be very challenging in terms of possible archaeological traces. In the same way, the specialisation and intensification of potterymaking methodologically meant other forms of discontinuity through the material record and a strong connection to gender.

\section{Encountering desechos}

Desechos are main features of Aguabuena and refer to the broken ceramic sherds that line the unstable paths across the steep and mountainous landscape. Desechos populate and construct this world and are key aspects in thinking through discontinuity.

Thousands of coarse pottery fragments of all sizes and different periods lie in Aguabuena: they ground existence in various ways. In fact, broken pots remain visible, transformed rapidly by their redundant exposure from special details 
Figure 11. Broken or damaged pots waiting to become part of the pavement of a road. Picture taken in 2010 .

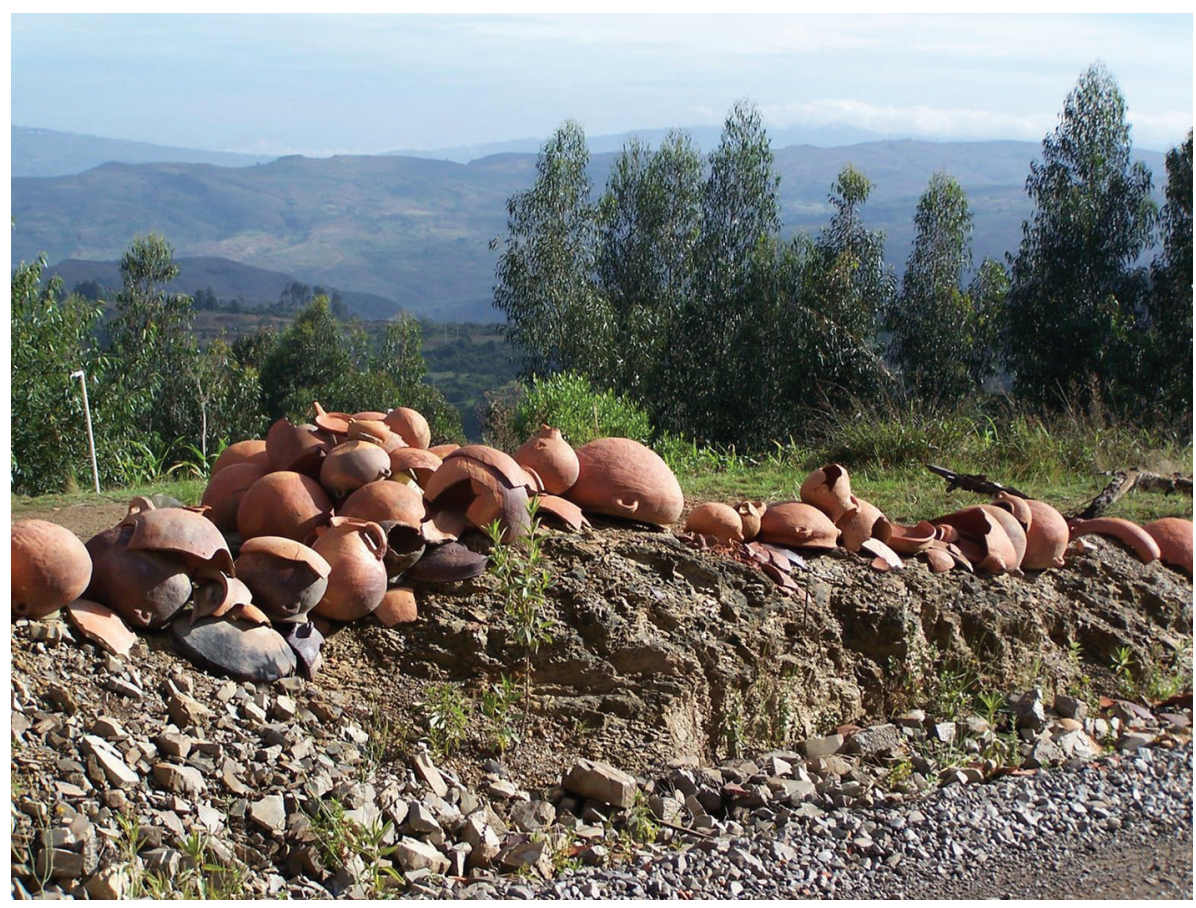

into ones to be ignored; sherds are everywhere. Discretely piled outside or inside ceramic workshops, sometimes as improvised walls to act as windbreaks, or used as materials for constructing houses, sherds can be used for different purposes. Some also act as pavements for secondary roads or part of the underground matrix of the soil strata (Figure 11). Fragments endure while continuing to fragment further because of the wind, dust and dryness that contribute to the erosion of the place, while adding a special texture and colour to the naked surfaces of Aguabuena's mountainous landscape.

In such a context, ceramic waste lies on the surface and becomes the surface itself, just as many different materials are found on the ground (Castellanos, 2020). For example, an old timber kiln in a state of ruination stands beside pottery fragments, some of which belong to los antiguos, some to current potters. Thus, on the exposed fields with no grass, fragments from different times lay next to each other, with no clear association except for the processes (both natural and human) of being discarded and that left them there. These processes have not fixed things in certain areas but contributed to the abrupt changes of the material record, as sherds are reused for different activities.

As shown earlier, my initial research proved the dynamic life of ceramic waste, since, contrary to my expectations, most of the broken pots were kept for potential reuse (stored, piled, or just scattered in the household or plots). For example, more than merely a dumping spot, a pile of fragments from different workshops on the road meant a cluster of current and past pieces, used as artisanal pavement that would reveal how sherds also shape and embed movement - and how going uphill or downhill in Aguabuena often meant moving across broken pieces of pottery.
This was clear to me during the several religious processions in which I, accompanying my host family while following the monks, stepped on sherds throughout the whole path, also noticing their clinking as our feet caused them to crack and collide with the surrounding sharp-angled ceramic waste. This was not such a minor detail, if one thinks (and bodily later bearing the consequences) of the numerous hours that the processions would last (at least six hours) and the corporeal experience of walking on uneven materials, a soil of ceramics - some curved, some sharp, mostly orange, but all musical. Moving across such spaces involved certain (ceramic) aesthetics in which destruction and creation conjoined (Castellanos, 2021). Cars and motorbike drivers have also been aware of this, as they tend to be cautious of driving on these roads during rainy months, arguing that the mud and the ceramic pieces make them a truly pista de jabón (literally a 'soapy road'; i.e. very slippery).

\section{Revisiting pottery-making}

This article has been an attempt to think through discontinuity as it is ethnographically revealed in the field and to pursue its analytical implications for our studies in pottery-making. Since my first visit to Aguabuena in the early 2000s, I have been confronted with several changes dealing with fractures and ruptures of various kinds that have shown the great dynamism of pottery-making, an activity otherwise represented as more static in Colombian archaeology.

Among the most striking and obvious forms of discontinuity stand the cracks of pots and the ceramic sherds. As I have shown, these fragments are not inert matter but continue to act on the world as reused vessels inside ceramic 
workshops, (dis)connecting paths or being the traces of los antiguos. These forms of agency have led me to think of the creative role of fragments and the role of pottery-making in producing them and, by this token, the discontinuousness as a locus of emerging possibilities both for (re)production of life and theory.

Besides material discontinuity, I have considered other social forms of discontinuity seen spatially at different scales and with material implications. As shown earlier in the text, Aguabuena has both increased and decreased its population depending on the demand for ceramics as much as the desire to make a living by different and less exploitable means, desires which stand closer to the potters' ideals for modernity. Alongside these changes, workshops have emptied and been locked, re-inhabited and re-opened. Some have been abandoned for good and started to fall into ruin, while some other empty workshops are being inhabited by other families of potters who have moved in (or families from urban places). These fragmentations also represent breaks within the household, as families move within the same territory or outside Aguabuena, or their children grow, have their own families, and choose not to continue doing pots.

Today, pottery communities are in many ways disappearing. Other scholars, like me, have written about the decreasing number of living potters and the non-continuation of the craft by younger generations within the families of long and established pottery-making traditions (see, for example, García-Roselló, 2008; 2017). This apparent end of craft communities is, of course, relative, since pottery-making is always a survival possibility for those families who return to their original territories after unsuccessful migration or take up the craft again when the market is in demand of ceramic pots.

This idea of the diminishment of craft communities, links to the presence of discontinuity in the social memory, a point also explored in the text. Through the ruins and concept of los antiguos, Aguabuena narratives of the past are neither lineal nor anchored in the atemporal indigenous time some scholars tend to reproduce in their analysis. Instead, potters' representations on their own history embraces the colonial world through the fluid exchanges they acknowledge between their ancestors and other actors - like the clerks who came from Spain in the late $16^{\text {th }}$ century.

The torneta arrived too, as part of the lively exchanges the potters have with others. Brought by commercial middlemen, it came to Aguabuena as a foreign tool together with other firing technologies like the coal-kiln, changes to which potters adapted by making men become fully involved in the manufacturing processes. However, as the steelmade tournette gained more popularity, the ceramic plato continued to be present. This coexistence of two rudimentary spinning devices unfolds a scenario where discontinuity is present with different nuances.

The wheel has propelled changes in the modes of production and gender division of work. Moreover, it informs us of the marginal and exploitative condition of potters within a larger economic structure of the craft market. It also talks about the relation to the past, as ceramic platos are also part of the material record of los antiguos, and of today's old women potters' role inside the ceramic workshop. Some platos stand abandoned in a corner of the workshop or are being used for different purposes than shaping pots, while the tornetas are being used less in times of decreasing craft production. In this sense, the potter's wheel becomes a hallmark of disruption in terms of what is put aside, or left behind, potentially reusable and resignified, telling both of the (non-lineal) past and the potters' strivings for the future. This last point is worth considering as it brings our attention to the different temporalities displayed on the surfaces of the ethnographic present.

\section{References}

ARNOLD III, P.J., 1991. Domestic Ceramic Production and Spatial Organization: A Mexican Case Study in Ethnoarchaeology. Cambridge: Cambridge University Press.

ARNOLD, D., 1985. Ceramic Theory and Cultural Process. Cambridge: Cambridge University Press.

BORDA, O.F., 1979. El hombre y la tierra en Boyacá: desarrollo histórico de una sociedad minifundista. Bogotá: Punta de Lanza.

BROADBENT, S.M., 1974. Tradiciones Cerámicas de las Altiplanicies de Cundinamarca y Boyacá. Revista Colombiana de Antropología, 16, 223-248.

CASTELLANOS, D., 2004. Cultura material y organización espacial de la producción cerámica en Ráquira. Un modelo etnoarqueológico. Bogotá: Fundación de Investigaciones Arqueológicas Nacionales, Banco de la República.

CASTELlANOS, D., 2015. The Ordinary Envy of Aguabuena People: Revisiting Universalistic Ideas from Local Entanglements. Anthropology and Humanism, 40(1), 20-34.

CASTELlANOS, D., 2020. Caminar desechos. Reflexiones desde las superficies de Aguabuena. Bulletin de l'Institut Français d'Études Andines, 49(1), 41-62.

COSTIN, C.L., 1991. Craft specialization: issues in defining, documenting and explaining the organization of production. Archaeological Method and Theory, 3, 1-56.

CHAVES, M., MONTENEGRO, M., and ZAMBRANO, M., eds., 2014 El valor del patrimonio: mercado, políticas culturales y agenciamientos sociales. Bogotá: Instituto Colombiano de Antropología e Historia.

DAVID, N., and KRAMER, C. 2001. Ethnoarchaeology in Action. Cambridge: Cambridge University Press.

FALCHETTI, A.M., 1975. Arqueología de Sutamarchán, Boyacá. Bogotá: Banco Popular.

GARCÍA-ROSEELLÓ, J., 2008. Etnoarqueología de la producción cerámica. Identidad y territorio en los valles centrales de Chile. Mayurqa. Revista Annual d'Història, 32, Palma: Universitat del es Illes Balears.

GARCÍA-ROSEELLÓ, J., 2017. Cerámica, prácticas técnicas y estructura social mapuche: un caso de dinamismo cultural. Complutum, 28(2), 341-357.

GNECCO, C., and LANGEBAEK, C.H., 2006. Contra la tiranía tipológica en arqueología: una visión desde Suramérica. Bogotá: Universidad de los Andes.

GORDILLO, G.R., 2014. Rubble. The Afterlife of Destruction, Durham and London: Duke University Press.

GOULD, R., and WATSON, P.J., 1982. A dialogue of the meaning and use of analogy in ethnoarchaeological reasoning. Journal of Anthropological Archaeology, 1(4), 355-381.

HENARE, A., HOLBRAAD, M., and WASTELL, S. 2007. Thinking Through Things: Theorising Artefacts Ethnographically. London: Routledge.

KNAPPET, C., and VAN DER LEEUW, S., 2014. A Developmental Approach to Ancient Innovation: The potter's wheel in the Bronze Age east Mediterranean. Pragmatics \& Cognition, 22(1), 64-92. 
LANGEBAEK, C. 2012. Experiencias oníricas, el más allá y el purgatorio en la Nueva Granada. La demoniación de las entrañas americanas y la conversión de los indios. Boletín de Hiatoria y Antiguedades, 99, 251307.

LANGEBAEK, C. 2019. Los Muiscas. La historia milenaria de un pueblo chibcha. Bogotá: Editorial Debate.

LOBOGUERRERO, J., 2001. Objetos cotidianos en la historia de la resistencia indígena en Colombia. Del documento de archivo al materia arqueológico. Revista de Antropología y Arqueología, 13, 26-48.

MANTILLA OLIVEROS, J.C. 2016. Arqueología y comunidades negras en América del Sur: problemas y perspectivas. Vestigios-Revista LatiniaAmericana de Arqueología Histórica, 10(1), 16-35.

MINISTERIO DE CULTURA, 2014. Ráquira. De la casa a la olla. Bogotá: División de Patrimonio, Ministerio de Cultura.

MORA DE JARAMILLO, Y., 1974. Cerámica y ceramistas de Ráquira. Bogotá: Museo Arqueológico Casa del Marqués de San Jorge, Banco Popular.

OME, T., 2006. De la ritualidad a la domestividad en la cultura material. un análisis de contextos significativos del tipo cerámico Guativita Desgrasante Tiestos entre los periodos Prehispánico, Colonial y Republicano (Santafé de Bogotá). Bogotá: Departamento de Antropología, CESO, Universidad de los Andes.

ORBELL, J., 1995. Los herederos del Cacique Suaya. Historia colonial de Ráquira (1539-1810). Bogotá: Banco de la República.

PATIÑO CASTAÑO, D., and HERNÁNDEZ, M.C. 2020. Arqueología e historia de afrodescendientes en el Cauca, Colombia. Revista Colombiana de Antropología, 57(1), 125-162.

RAPPAPORT, J. 2018. El mestizo evanescente: configuración de la diferencia en el Nuevo Reino de Granada. Bogotá: Editorial Universidad del Rosario.
RASMUSSEN, D.M., 2010. Análisis espacio-temporal del cambio en los bosques de roble (Quercus Humboldtii Bonpl). Revista Colombia Forestal, 13(2), 275-298.

ROUX, V. 2003. A dynamic systems framework for studying technological change: application to the emergence of the potter's wheel in the southern Levant. Journal of Archaeological Method and Theory, 10(1), 1-30.

ROUX, V., and COURTY, M-A., 2013. Introduction to discontinuities and continuities: Theories, methods and proxies for a historical and sociological approach to evolution of past societies. Journal of Archaeological Method and Theory, 20(2), 187-193.

SCHIFFER, M., 1995. Behavioral Archaeology: First Principles. Salt Lake City: University of Utah Press.

SILLAR, B., and RAMÓN JOFFRÉ, G., 2016. Using the present to interpret the past: the role of ethnographic studies in Andean archaeology. World Archaeology, 48(5), 656-673.

THERRIEN, M., 1991. Basura arqueológica y tecnología cerámica. Estudio de un basurero de taller cerámico en el resguardo colonial de Ráquira, Boyacá. Unpublished thesis (MA), Universidad de los Andes.

THERRIEN, M., 2016. Displacing Dominant Meanings in the Archaeology of Urban Policies and Emergence of Santafé de Bogotá (Colombia). In: S. Montón-Subías, M. Cruz, and A. Ruiz, eds. Archaeologies of Early Modern Spanish Colonialism. Switzerland: Springer, 11-38.

THERRIEN, M., UPRIMMY, E., LOBOGUERRERO, J., SALAMANCA, M.F., GAITÁN, F., and FANDIÑO, M., 2002. Catálogo de cerámica colonial y republicana de la Nueva Granada: producción local, materiales foráneos (Costa Caribe, Altiplano cundiboyacense, Colombia). Bogotá: Fundación de Investigaciones Arqueologógicas Nacionales.

VASCO, L.G., 1987. Semejantes a los dioses: cerámica y cestería EmberáChami. Bogotá: Universidad Nacional de Colombia. 
